\title{
Assessing urology and nephrology research activity in Arab countries using ISI web of science bibliometric database
}

\author{
Waleed M Sweileh ${ }^{1 *}$, Sa'ed H Zyoud ${ }^{2}$, Samah W Al-Jabi ${ }^{2}$ and Ansam F Sawalha'
}

\begin{abstract}
Background: Bibliometric analysis is increasingly being used for research assessment. The main objective of this study was to assess research output in Urology and Nephrology subject from the Arab countries. Original scientific articles or reviews published from the 21 Arab countries in "Urology and Nephrology" subject were screened using the ISI Web of Science database. Research productivity was evaluated based on a methodology developed and used in other bibliometric studies by analyzing the annual productivity, names of journals, citations; top 10 active institution and authors as well as country contribution to Urology and Nephrology research.

Results: Three thousand and seventy six documents in "urology and nephrology" subject category were retrieved from 104 journals. This represents $1.4 \%$ of the global research output in "urology and nephrology". Four hundred and two documents (12.66\%) were published in Annales D Urologie Journal. The $h$-index of the retrieved documents was 57. The total number of citations, at the time of data analysis, was 30401 with an average citation of 9.57 per document. Egypt, with a total publication of 1284 (40.43\%) ranked first among the Arab countries in "urology and nephrology" subject category. Mansoura University in Egypt was the most productive institution with a total of 561 (15.33\%) documents. Arab researchers collaborated most with researchers from the United States of America (226; 7.12\%) in urology and nephrology research.

Conclusion: The present data reveals a good contribution of some Arab countries to the field of "urology and nephrology". More efforts are needed by some other Arab countries to bridge the gap in urology and nephrology research. Overall, the quality of urology/nephrology research is considered relatively high as measured by $h$-index. Cooperation in urology/nephrology research should be encouraged in the Arab world to bridge the gap with that from developed countries.
\end{abstract}

Keywords: Bibliometric, Urology and nephrology, Arab world, ISI Web of science

\section{Background}

Medical education and clinical practice in many Arab countries have witnessed a dramatic change in the past three decades. Many medical schools, hospitals, and specialized medical research centers have been established. Research in the medical field reflects excellence and quality of medical education and clinical practice. Actually, quality and quantity of research output in any health subject reflects country's interest and efforts to provide better health standards to the people of that country. One method to

\footnotetext{
* Correspondence: waleedsweileh@yahoo.com

'Department of Pharmacology and Toxicology, College of Medicine and

Health Sciences, An-Najah National University, Nablus, Palestine

Full list of author information is available at the end of the article
}

assess research output from any country is Bibliometric analysis which refers to the implementation of statistical methods for evaluating the research productivity, for individuals, institutes and countries [1]. Bibliometric analysis is a useful tool to obtain information about the current state of research in particular areas and allows researchers to identify and undertake new lines of research [2]. Bibliometrics has been applied to various diseases and is now widely accepted as a method of measuring research and literacy output in any particular area [3-8].

It is believed that medical research output from Arab countries is still lagging behind compared to non-Arab countries in the region like Israel, Turkey or Iran [9-14]. However, Egypt has surpassed Israel in Urology research 
but lags behind Israel in cardiology research [15]. Historically speaking, Arabs have made valuable contribution to medicine and urology [16]. Actually, pharmacological and surgical aspects of urology has been known in ancient Egypt [17]. Urology and nephrology are subjects of great importance in the Arab world since risk factors for such diseases, like diabetes mellitus, hypertension and obesity are prevalent in the Arab world. According to International Diabetes Federation, 6 out of the world's top ten countries for highest prevalence (\%) of diabetes are in the Middle East and North Africa Region-Kuwait, Lebanon, Qatar, Saudi Arabia, Bahrain and the United Arab Emirates [18]. Prevalence of hypertension, another important risk factor for chronic kidney disease (CKD), is also believed to be high among Arabs [19-21]. A recent mini review indicated that there is an urgent need for epidemiological studies about CKD in the Arab countries [22]. Arab researchers have established several peer reviewed journals dedicated for Urology and nephrology to encourage Arab researchers in this field [23].

The objective of this study was to analyze research output from 21 Arab countries in Urology and Nephrology. The Arab countries cover a large geographic area including North Africa and the Arabic Peninsula with around 500 million inhabitants. Studies regarding Urology and Nephrology research output have been published from several areas in the world [23-25]. However, up to the authors' knowledge, no reports have been published from the Arab world about bibliometrics of research activity in "Urology and Nephrology" from the Arab world. Such bibliometric study will lead to a better understanding of the current and future status of Urology and Nephrology research in the Arab world which, hopefully, can lead to better preventive disease strategies and better patientoriented health services [26-31]. The results of the study will help health policy makers and people in academia and clinical practice to shape up Urology and Nephrology research in the future. In addition, the momentum of research activity needs to be maintained through continuous analysis of publications from researchers in the region to provide feedback to academics, health institutions, and education planners.

\section{Methods}

The data used in this study were based on the ISI Web of Science, which is one of the world largest databases of peer-reviewed literature. The world-leading citation databases provide authoritative, multidisciplinary coverage from more than 12,000 high impact research journals worldwide [32]. All Arab countries: Kingdom of Saudi Arabia (KSA); Egypt; Jordan; Lebanon; Qatar; Bahrain; Kuwait; Morocco; Tunisia; Syrian Arab Republic (SAR); United Arab Emirates (UAE); Iraq; Sudan; Yemen; Algeria; Comoros; Djibouti; Libya; Mauritania; Oman; Somalia, except Palestine, were used as country keys followed by "Urology and Nephrology" phrase as Web of Science Category. Palestine was excluded from search keys because the Web of Science database does not recognize Palestine as an independent state yet. The search keys looked like this: $(\mathrm{CU}=($ Jordan $) \mathrm{OR} \mathrm{CU}=$ (Iraq) OR CU $=$ (Syria) OR CU $=$ (Saudi) OR CU $=$ (Kuwait) OR CU $=$ (Egypt) OR CU $=($ Yemen $)$ OR CU $=($ Qatar $)$ OR $\mathrm{CU}=($ Emirates $)$ OR $\mathrm{CU}=($ Bahrain $)$ OR $\mathrm{CU}=($ Oman $)$ $\mathrm{OR} C U=($ Sudan $)$ OR CU $=($ Tunisia $)$ OR $C U=($ Algeria $)$ OR CU $=($ Lebanon $)$ OR CU $=($ Libya $)$ OR CU $=($ Morocco $)$ OR $\quad \mathrm{CU}=($ Somalia $) \quad \mathrm{OR} \quad \mathrm{CU}=($ Djibouti $) \quad \mathrm{OR} \quad \mathrm{CU}=$ (Comoros) $\mathrm{OR} \mathrm{CU}=($ Mauritania $))$ AND $\mathrm{WC}=($ Urology and Nephrology). To increase the accuracy of results, research was refined and limited to original research articles and review articles because they represent the research activities, while other types of documents like editorials, conference proceedings, and others were excluded. The time frame for the result was up to year 2011. The 2012 and 2013 years were excluded because they are still open of new journal issues.

The database then generates a count of the total number of original articles, the total citations, and the value of the $h$-index (highly cited index). The $h$-index represents the number of citations received for each of the documents in descending order, while the h-graph measures the impact of a set of documents and displays the number of citations per document (for example: $\mathrm{h}$-index of 10 means that there are 10 items that have 10 citations or more). The h-index was originally developed as a measure of qualifying research performance [33,34]. The collected data were used to generate the following information: (a) total and trends of contributions in Urology and Nephrology research during all previous years up to the set date of data analysis (December 31th, 2011); (b) Arab countries research productivity and collaboration patterns; (c) journals in which Arab world researchers published; and (d) the citations received by the publications.

\section{Ethical approval}

The Institutional Review Board (IRB) at An-Najah National University does not require submission of an IRB application for such study. The IRB considered that there is no risk for human subjects in such publications since the data are based on published literature and did not involve any interactions with human subjects.

\section{Statistical analysis}

Data from ISI Web of Science were exported to Microsoft Office Excel $^{\circ}$ and then transferred to the Microsoft word program. The measurements of bibliometric analysis (e.g. countries, cited articles, institutions) were converted to the rank order using the standard competition 
ranking (SCR). We took into consideration the top 10 ranking in each item. If the measurements of bibliometric analysis have the same ranking number, then a gap is left in the following ranking numbers. The journal's impact factors (IF) were evaluated using the Journal Citation Report (JCR; Web of Knowledge) 2012 science edition by Thomson Reuters (New York, NY, USA).

\section{Results}

The total number of documents retrieved from ISI Web of Science using "Urology and Nephrology" subject category without specifying the name of any country was 224,479 . This number represents the global research productivity (original research articles and reviews) in urology and nephrology subject up to year 2011. When the same methodology was applied using the list of the $21 \mathrm{Arab}$ countries, 3176 documents were retrieved. Therefore, research output in urology and nephrology from Arab countries represents $1.4 \%$ of the global research productivity in urology and nephrology. The 3176 consisted of 3049 (96.0\%) original journal articles, and 127 (4\%) review articles. The annual number of documents published from Arab countries indicated that urology and nephrology research output remained low until mid-1990s (Figure 1). More than $50 \%$ of documents were published after the year 2001. The language of most documents was English (2366; 74.5\%) followed by French $(788 ; 24.81 \%)$, Dutch (14; $0.44 \%)$ and Spanish $(8 ; 0.25 \%)$. The first urology and nephrology article from Arab countries was published in 1972 in Annales d'Urologie by Dr. Said, H from Tunisia and the title of the article was "Pelvic and lower lumbar ectopy of kidney in children-with 7 case reports" [35]. Figure 2 shows the changes in the total number of citations in each year which reflects the changes in quality of publication in urology \& nephrology from Arab countries.

The retrieved documents were published in 104 peerreviewed urology and nephrology journals registered in Web of Knowledge ${ }^{\circ}$. Four hundred and two articles (12.66\%) were published in Annales D Urologie Journal which started in 1969 and was discontinued as of 2007. Table 1 lists the top 10 journals in which documents in urology and nephrology were published from the Arab countries. Of the 3176 urology and nephrology documents, there were 131 documents in the transplantation, 111 in the pediatric and 47 in the obstetric/gynecology research area. Other overlapping research areas of documents in urology and nephrology field are shown in Table 2.

When retrieved data were analyzed by country (Table 3), Egypt (1248; 40.43\%) had the highest research output followed by Morocco $(553 ; 17.41 \%)$ and Kingdom of Saudi Arabia (513; 16.15\%). No data related to urology and nephrology was found from Djibouti, Mauritania and Comoros. Researchers from other countries have collaborated with researchers in the Arab world in Urology and Nephrology. Countries whose researchers collaborated most with researchers in the Arab world include the United States of America (USA); (226; 7.12\%) followed by France (102; $3.21 \%$ ) and Canada (98; 3.09\%) (Table 4). The total number of citations, at the time of data analysis (February $16^{\text {th }}$, 2014), was 30401 with an average citation of 9.57 per document. Of the 3176 documents considered for the $h$-index,

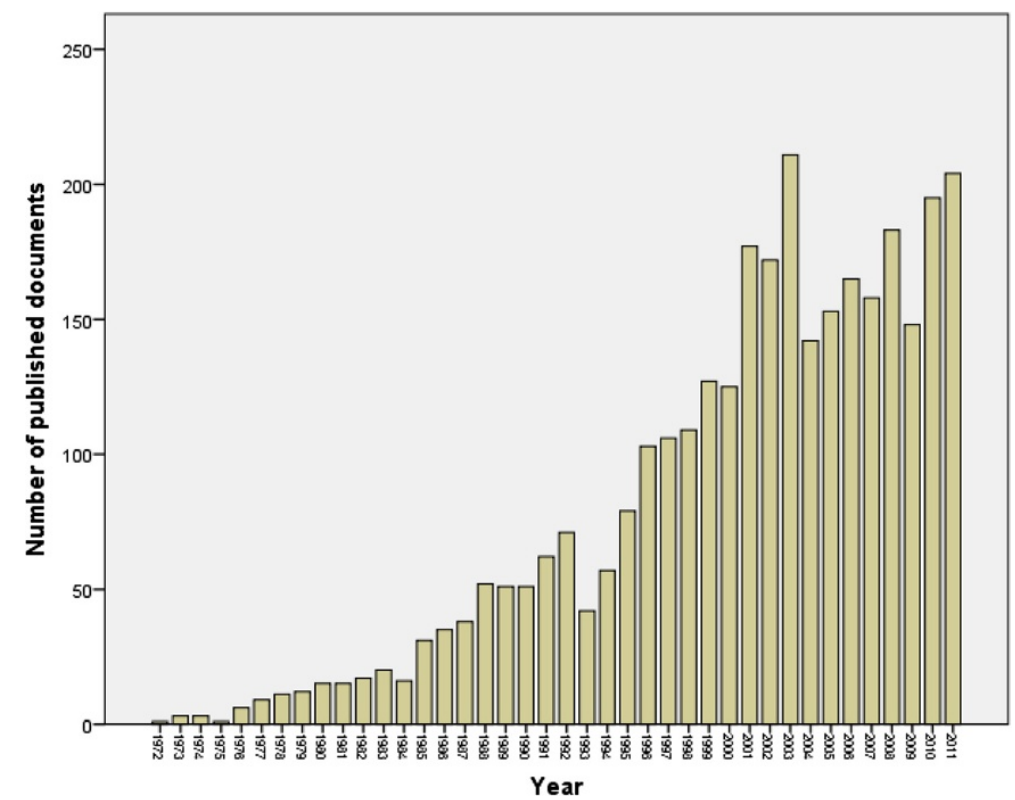

Figure 1 Growth of urology/nephrology research in Arab countries as extracted from ISA web of science using urology and nephrology as Web of Science Category. 


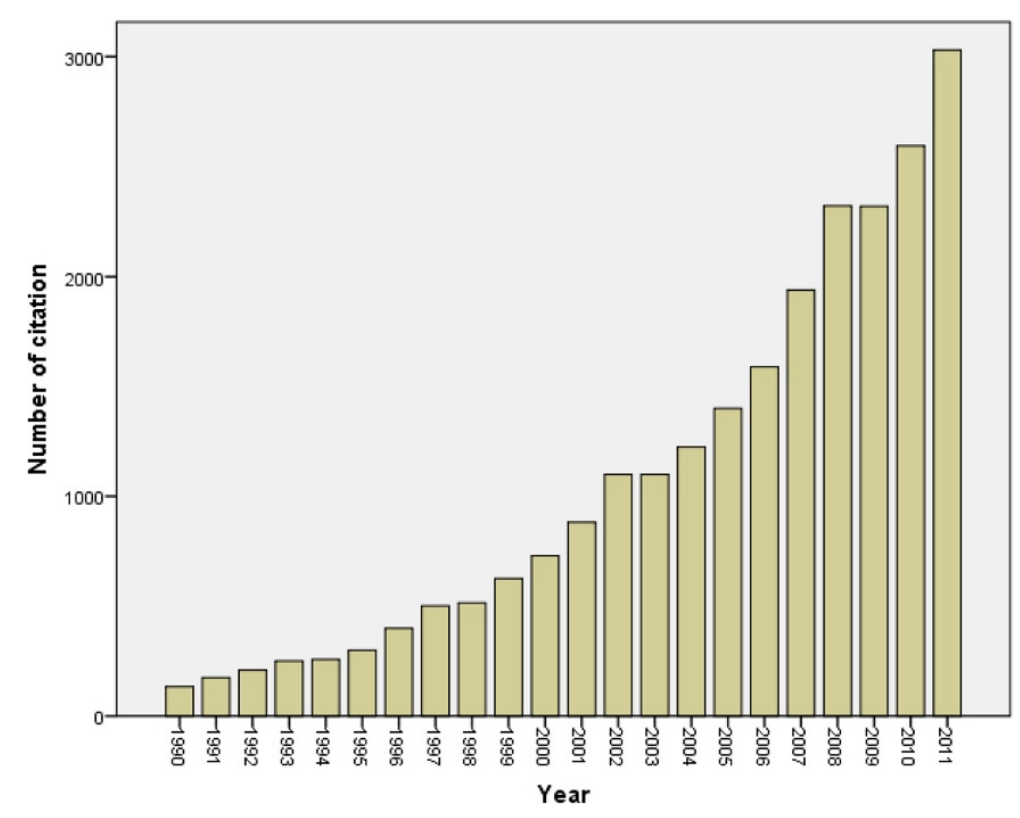

Figure 2 Changes in total number of citation in the past 2 decades for urology \& nephrology documents published from Arab countries.

57 had been cited at least 57 times at the time of data analysis.

Table 5 shows the top 10 most productive Arabic institutions in urology and nephrology field. The most productive institution was Mansoura University (561; 17.71\%). Table 6 presents the top 10 ranking of prolific authors who published in urology and nephrology field from the Arab world with their affiliations. Table 7 presents a list of the 10 most cited urology and nephrology articles originated from Arab countries [36-45]. It is noteworthy that 9 out of the top 10 cited articles from Arab countries were in clinical urology/nephrology rather than basic science of urology/ nephrology.

\section{Discussion}

In the present study, bibliometric analysis of Urology and Nephrology research activity from 21 Arab countries was carried out. Our study analyzed a total of 3167 documents extracted from ISI Web of Science using Subject key (Urology and Nephrology) and using country affiliation of the 21 Arab countries. Therefore, our results do not include Urology and Nephrology literature outside

Table 1 Top 10 journals in which urology and nephrology documents from the 21 Arab countries were published

\begin{tabular}{|c|c|c|c|}
\hline \multirow[t]{2}{*}{$\mathrm{SCR}^{\mathrm{a}}$} & \multirow[t]{2}{*}{ Journal name } & Number of documents & $\mathrm{IF}^{\mathbf{b}}$ \\
\hline & & \multicolumn{2}{|l|}{$N(100 \%)=3176$} \\
\hline $1^{\text {st }}$ & Annales D Urologie & $402(12.66)$ & $N A^{c}$ \\
\hline $2^{\text {nd }}$ & Journal of Urology & $313(9.86)$ & 3.696 \\
\hline $3^{\text {rd }}$ & BJU International (British Journal of Urology) & $307(9.67)$ & 3.046 \\
\hline $4^{\text {th }}$ & Progres en Urologie & $225(7.08)$ & 0.801 \\
\hline $5^{\text {th }}$ & Urology & $207(6.52)$ & 2.424 \\
\hline $6^{\text {th }}$ & Journal of Sexual Medicine & $97(3.05)$ & 3.513 \\
\hline $6^{\text {th }}$ & Nephrology Dialysis Transplantation & $97(3.05)$ & 3.371 \\
\hline $6^{\text {th }}$ & Scandinavian Journal of Urology and Nephrology & $97(3.05)$ & 1.007 \\
\hline \multirow[t]{2}{*}{$9^{\text {th }}$} & Journal D Urologie & \multirow[t]{2}{*}{$94(2.96)$} & \multirow[t]{2}{*}{2.708} \\
\hline & Changed to Archives of Dermatological Research & & \\
\hline $10^{\text {th }}$ & Journal of Endourology & $89(2.80)$ & 2.074 \\
\hline
\end{tabular}

Abbreviations: SCR standard competition ranking; NA not available; IF impact factor.

${ }^{a}$ Equal journals have the same ranking number, and then a gap is left in the ranking numbers.

${ }^{\mathrm{b}}$ The impact factor was reported according to Institute for Scientific Information (ISI) journal citation reports (JCR) 2012.

'Discontinued on 2007.

${ }^{d}$ Started on 1929 as British Journal of Urology and was discontinued on 1998. Continued as BJU International. 
Table 2 Research categories (WOS categorization) of the 3176 urology nephrology documents published from the 21 Arab countries

\begin{tabular}{ll}
\hline Research area & Number of documents \\
\hline Urology and nephrology & $3176(100)$ \\
Transplantation & $131(4.13)$ \\
Pediatrics & $111(3.50)$ \\
Obstetrics gynecology & $47(1.48)$ \\
Engineering & $34(1.07)$ \\
Endocrinology metabolism & $31(0.98)$ \\
Oncology & $28(0.88)$ \\
Physiology & $20(0.63)$ \\
Cardiovascular system cardiology & $15(0.47)$ \\
Hematology & $15(0.47)$ \\
Public environmental occupational health & $10(0.32)$ \\
Nutrition dietetics & $7(0.22)$ \\
Research experimental medicine & $4(0.13)$ \\
Gastroenterology hepatology & $2(0.06)$ \\
Cell biology & $1(0.03)$ \\
General internal medicine & $1(0.03)$ \\
Materials science & $1(0.03)$ \\
Pharmacology pharmacy & $1(0.03)$ \\
Surgery & $1(0.03)$ \\
\hline
\end{tabular}

ISI Web of Science database or literature published in journals not categorized in the field of urology and nephrology. For example, articles pertaining to urology and nephrology that were published in Arab Journal of Urology and in Saudi Journal of Kidney Diseases and Transplantation were not included in the analysis since these journals are not indexed in ISI Web of Science. Despite that, our study does give a clear picture about the characteristics of research from Arab countries published in international journals, especially those indexed by Web of Science under the category (Urology and Nephrology"). Although bibliometric analysis might slightly differ from one search engine to another, Web of Science search engine remains one of the best available tools for analyzing and tracking citations [46,47]. A study that compared PubMed, Scopus, Web of Knowledge, and Google Scholar has found that PubMed remains an important resource for clinicians and researchers, while Web of Knowledge covers a wider journal range and offers the capability for citation analysis [46-49].

The data obtained in our study will serve as a baseline data for evaluation of future research activities and for comparative purposes with other non-Arab countries. A study carried out to perform a bibliometric evaluation of publications from European Union (EU) countries in the
Table 3 Contribution of each Arab country to the 3176 documents published in the subject "urology and nephrology"

\begin{tabular}{|c|c|}
\hline Country & $\begin{array}{l}\text { Number of documents } \\
N(\%)=3176(100 \%)^{*}\end{array}$ \\
\hline Egypt & $1284(40.43)$ \\
\hline Morocco & $553(17.41)$ \\
\hline Kingdom of Saudi Arabia & $513(16.15)$ \\
\hline Tunisia & $374(11.78)$ \\
\hline Kuwait & $156(4.91)$ \\
\hline United Arab Emirates & 98 (3.09) \\
\hline Lebanon & $76(2.39)$ \\
\hline Jordan & $65(2.05)$ \\
\hline Qatar & $35(1.10)$ \\
\hline Sudan & $33(1.04)$ \\
\hline Iraq & $27(0.85)$ \\
\hline Oman & $26(0.82)$ \\
\hline Algeria & $25(0.79)$ \\
\hline Libya & $13(0.41)$ \\
\hline Yemen & $10(0.28)$ \\
\hline Bahrain & $7(0.22)$ \\
\hline Somalia & $4(0.13)$ \\
\hline Syria & $4(0.13)$ \\
\hline Comoros & $0(0.0)$ \\
\hline Djibouti & $0(0.0)$ \\
\hline Mauritania & $0(0.0)$ \\
\hline
\end{tabular}

*total exceeds $100 \%$ because of overlap in some documents among more than one Arab country.

Table 4 Top 10 countries whose researchers have collaborated with Arab researchers in publication of the 3176 documents in urology and nephrology

\begin{tabular}{lll}
\hline SCR & Country & $\begin{array}{l}\text { Number of documents } \\
\text { N (\%) }=\mathbf{3 1 7 6}(\mathbf{1 0 0 \% )}\end{array}$ \\
\hline $1^{\text {st }}$ & United States of America & $226(7.12)$ \\
$2^{\text {nd }}$ & France & $102(3.21)$ \\
$3^{\text {rd }}$ & Canada & $98(3.09)$ \\
$4^{\text {th }}$ & England & $84(2.65)$ \\
$5^{\text {th }}$ & Germany & $77(2.42)$ \\
$6^{\text {th }}$ & Netherlands & $39(1.23)$ \\
$7^{\text {th }}$ & Sweden & $34(1.07)$ \\
$8^{\text {th }}$ & Japan & $27(0.85)$ \\
$9^{\text {th }}$ & Belgium & $24(0.76)$ \\
$10^{\text {th }}$ & Italy & $23(0.72)$ \\
\hline
\end{tabular}


Table 5 Top 10 active institutions in the field of urology and nephrology in the 21 Arab countries

\begin{tabular}{llll}
\hline $\mathbf{S C R}^{\mathbf{a}}$ & Institute & Country & $\begin{array}{l}\text { Number of } \\
\text { documents }\end{array}$ \\
\hline $\mathbf{1}^{\text {st }}$ & Mansoura University & Egypt & $561(15.33)$ \\
$\mathbf{2}^{\text {nd }}$ & Cairo University & Egypt & $323(10.17)$ \\
$\mathbf{3}^{\text {rd }}$ & CHU Ibn Sina & $153(2.46)$ \\
$\mathbf{4}^{\text {th }}$ & Kuwait University & Morocco & $123(3.87)$ \\
$\mathbf{5}^{\text {th }}$ & King Saud University & Kuwait & KSA \\
$\mathbf{6}^{\text {th }}$ & King Faisal Specialist & KSA & $116(3.65)$ \\
$\mathbf{6}^{\text {th }}$ & Hospital Research Center & & $112(3.53)$ \\
$\mathbf{6}^{\text {th }}$ & CHU Ibnou Rochd & Morocco & $136(3.31)$ \\
$\mathbf{9}^{\text {th }}$ & HOP Charles Nicolle & Tunisia & $103(3.24)$ \\
$\mathbf{1 0}^{\text {th }}$ & Alexandria University & Egypt & $95(2.99)$ \\
\hline $\boldsymbol{A b b}^{\text {th }}$ & Ain Shams University & Egypt & $83(2.61)$ \\
\hline
\end{tabular}

Abbreviations: SCR standard competition ranking; KSA Kingdom of Saudi Arabia.

${ }^{a}$ Equal institutions have the same ranking number, and then a gap is left in the ranking numbers.

${ }^{b}$ represents productivity from Mansoura University and Urology Nephrology Center/Mansoura.

'represents CHU Ibn Sina, CHU AVICENNE and HOP AVICENNE.

${ }^{d}$ represents $\mathrm{CHU}$ Ibnou Rochd and $\mathrm{CHU}$ Ibn rochd.

international urological journals between 2000-2005 has indicated that such studies demonstrated a feasible solution to validate and compare the contribution of the various EU countries towards the urological research [50]. It is believed that basic and clinical research in urology and nephrology promotes clinical practice. For example, clinical research have promoted the development of nephrology in China [51].
The annual number of documents published under Urology and Nephrology category from the 21 Arab countries was acceptable although the general medical research activity from Arab countries is low [13,52-55]. Studies suggested that the lack of funding, freedom, and democracy may contribute to low scientific research output in the Arab world $[13,52,53,55]$. Our study showed that there were some countries, such as, Egypt and Morocco, KSA where their total research productivity was clearly higher than that in the remaining countries. Previous studies reported that Egypt and KSA had high biomedical and nephrology publications among the Arab countries $[13,56,57]$, which is consistent with the current results in the field of urology and nephrology research publications.

Our results showed that authors from Arab region mainly collaborated with authors from USA, France and Canada. This may be because most academics from Arab countries graduated from or were trained in these countries. International collaboration is beveled to increase the quantity and quality of research productivity [58,59]. Research collaboration is an important mechanism to improve quality and quantity of research at the university level. A study has found that there is a positive correlation between research productivity, funding, public impact and international and domestic collaboration at the author level [60-62]. A study has found that at article level, both within-university collaboration and international collaboration are positively related to an article's quality and that, at scientist-year level, only international collaboration is positively related to a scientist's future research output [63]. Other studies indicated that international collaboration can increase the visibility of scientific publication

Table 6 Ranking of the top 10 prolific authors who published in the field of urology and nephrology from the 21 Arab countries or who collaborated with authors located in the Arab countries

\begin{tabular}{|c|c|c|c|}
\hline $\mathrm{SCR}^{\mathrm{a}}$ & Author & $\begin{array}{l}\text { Number of published documents } \\
N(\%)=3176(100 \%)\end{array}$ & Affiliation as shown in ISI web of knowledge last publication \\
\hline $1^{\text {st }}$ & Ghoneim, M.A & $165(5.2)$ & Mansoura Univ, Dept Urol, Urol \& Nephrol Ctr, Mansoura, Egypt \\
\hline $2^{\text {nd }}$ & Shokeir, A.A & $116(3.65)$ & Mansoura Univ, Urol \& Nephrol Ctr, Dept Urol, Mansoura, Egypt \\
\hline $3^{\text {rd }}$ & Benchekroun, A & $107(3.37)$ & CHU Ibn Sina, Serv Urol A, Rabat, Morocco \\
\hline $4^{\text {th }}$ & Benjelloun, S & $104(3.28)$ & $\begin{array}{l}\text { Ctr Hosp Ibn Rochd, Serv Urol, 25, Rue Rome,Angle Rue Amsterdam, } \\
\text { Casablanca, Morocco. }\end{array}$ \\
\hline $5^{\text {th }}$ & Shafik, A & $88(2.77)$ & Cairo Univ, Dept Surg \& Expt Res, Fac Med, Cairo 11121, Egypt \\
\hline $6^{\text {th }}$ & Faik, M & $85(2.68)$ & CHU Rabat, Hop Ibn Sina, Serv Urol A, Rabat, Morocco \\
\hline $7^{\text {th }}$ & Lakrissa, A & $74(2.33)$ & Ibn Sina Hosp, Dept Urol B, Univ Teaching Ctr, Rabat, Morocco \\
\hline $8^{\text {th }}$ & Hachimi, M & $72(2.27)$ & CHU Ibn Sina, Serv Urol, Rabat, Morocco \\
\hline $8^{\text {th }}$ & Joula, A & $72(2.27)$ & CHU Ibnou Rochd, Serv Urol, Casablanca, Morocco \\
\hline $10^{\text {th }}$ & Ayed, M & $68(2.14)$ & Hop Charles Nicolle, Dept Urol, Tunis, Tunisia \\
\hline
\end{tabular}

Abbreviation: SCR standard competition ranking.

${ }^{a}$ Equal authors have the same ranking number, and then a gap is left in the ranking numbers.

${ }^{b}$ Percentage of publications for each author by the total number of documents. 
Table 7 Top 10 cited articles in the subject "urology and nephrology" that were authored/ co-authored by researchers from 21 Arab countries

\begin{tabular}{|c|c|c|c|c|c|}
\hline SCR & Article title & Name of journal & Year; authors as shown in ISI & $\begin{array}{l}\text { Type of study (Basic } \\
\text { versus Clinical) }\end{array}$ & Number cited \\
\hline $1^{\text {st }}$ & $\begin{array}{l}\text { Laparoscopic versus open radical nephrectomy: } \\
\text { A 9-year experience }\end{array}$ & Journal of Urology & 2000; Dunn, MD; Portis, AJ; Shalhav, AL; et al. [36] & Clinical & 319 \\
\hline $2^{\text {nd }}$ & $\begin{array}{l}\text { Worldwide ethnic distribution of the G protein beta } 3 \\
\text { subunit } 825 \text { T allele and its association with obesity in } \\
\text { Caucasian, Chinese, and Black African individuals }\end{array}$ & $\begin{array}{l}\text { Journal of the American Society } \\
\text { of Nephrology }\end{array}$ & 1999; Siffert, W; Forster, P; Jockel, KH; et al. [37] & Basic & 265 \\
\hline $3^{\text {rd }}$ & $\begin{array}{l}\text { Radical cystectomy for carcinoma of the bladder: } \\
\text { Critical evaluation of the results in } 1,026 \text { cases }\end{array}$ & Journal of Urology & 1997; Ghoneim, MA; ElMekresh, MM; ElBaz, MA; et al. [38] & Clinical & 240 \\
\hline $4^{\text {th }}$ & $\begin{array}{l}\text { An International Urogynecological Association (IUGA)/ } \\
\text { International Continence Society (ICS) joint report on } \\
\text { the terminology for female pelvic floor dysfunction }\end{array}$ & $\begin{array}{l}\text { International Urogynecology } \\
\text { Journal }\end{array}$ & $\begin{array}{l}\text { 2010; Haylen, Bernard T.; de Ridder, Dirk; Freeman, } \\
\text { Robert M.; et al. [39] }\end{array}$ & Clinical & 218 \\
\hline $5^{\text {th }}$ & Vascular access for hemodialysis & Kidney International & 1999; Schwab, SJ; Harrington, JT; King, AJ; et al. [40] & Clinical & 204 \\
\hline $6^{\text {th }}$ & $\begin{array}{l}\text { Nerve-sparing robot-assisted radical cystoprostatectomy } \\
\text { and urinary diversion }\end{array}$ & BJU International & 2003; Menon, M; Hemal, AK; Tewari, A; et al. [41] & Clinical & 199 \\
\hline $7^{\text {th }}$ & $\begin{array}{l}\text { Extended radical lymphadenectomy in patients with urothelial } \\
\text { bladder cancer: Results of a prospective multicenter study }\end{array}$ & Journal of Urology & 2004; Leissner, J; Ghoneim, MA; Abol-Enein, H; et al. [42] & Clinical & 193 \\
\hline $8^{\text {th }}$ & $\begin{array}{l}\text { Causes, kinetics and clinical implications of } \\
\text { post-hemodialysis urea rebound }\end{array}$ & Kidney International & 1988; Pedrini, LA; Zereik, S; Rasmy, S. [43] & Clinical & 174 \\
\hline $9^{\text {th }}$ & The burden of kidney disease: Improving global outcomes & Kidney International & 2004; Eknoyan, G; Lameire, N; Barsoum, R; et al. [44] & Clinical & 144 \\
\hline $10^{\text {th }}$ & $\begin{array}{l}\text { Laparoscopic nephroureterectomy for upper tract transitional } \\
\text { cell cancer: The Washington University experience }\end{array}$ & Journal of Urology & 2000; Shalhav, AL; Dunn, MD; Portis, AJ; et al. [45] & Clinical & 142 \\
\hline
\end{tabular}


from a particular country [64]. Furthermore, international collaboration in research helps in capacity building in developing countries and make national problems of developing countries more observable [65].

Research output studies in the field of Urology and Nephrology have been conducted in several parts of the world [23-25,50,66-69]. A recent Iranian study using Medline database and the IranMedex between 1997 and 2007 reported that (1) the total number of publications in the field kidney disease from Iran was 579 (average of 58 papers per year); (2) more than $56 \%$ of the publications (324) were in journals that were indexed in the Medline; and (3) the majority of the papers were concerned with transplantation (58.3\%), nephrology (20.0\%), and hemodialysis (16.8\%). Authors of the Iranian study concluded that Iran's contribution to the research on kidney disease is not satisfactory in terms of the volume and quality of publications. On the other hand, the data suggest that there was a significant research activity in the field of kidney transplantation during the studied period [24]. A Japanese study indicated that Japan's share of research output for selected journals in urology and nephrology was $6 \%$ and it ranked second in the world following the USA [66]. A study analyzed the characteristics of highly cited articles showed that highly cited articles are very different from 'ordinary' cited articles and that highly cited articles are usually authored by a large number of scientists and often involving international collaboration [70]. Highly cited articles positively contribute to the $h$-index of the individual author and to the institution and country [71-74]. The citation is a key indicator of research quality and researchers need to be aware of mechanisms that might enhance citation of published articles like self-citation whenever possible [75].

To the best of the authors' knowledge, our study is the first article to analyze the quantity and quality of research productivity in the field of urology and nephrology from the Arab world. Our study showed that some Arab countries, such as Egypt and KSA, clearly had higher research urology and nephrology research output than the remaining Arab countries. This high activity is due to population, national income and overall scientific activity of these countries. The main goal of this paper was to direct attention and to open the doors for a scientific discussion among professionals and academics. It is recommended that similar quantitative and qualitative research analyses for other disciplines, based on the same methodology, should be made for Arab countries. This would provide a more comprehensive picture of the overall research productivity both at the regional level and at the international level.

Finally, our study is not without limitations, most of which are the same as those of studies performed in other biomedical fields $[7,8,14,76]$. First of all, we used ISI web of knowledge database and therefore articles published in elsewhere were not included. Second, many articles in urology and nephrology might have been published in nonurology/non-nephrology journals.

\section{Conclusion}

The present data show promising and relatively good urology/nephrology research productivity from Arab countries especially in the last decade. However, wide variation in research productivity among Arab countries in urology/ nephrology do exists. Egypt is the leading country in this regard and Mansoura University is leading institution in Arab country in the field of urology/nephrology research. The quality of urology/nephrology research from Arab countries is also good and promising. The methodology used in this manuscript can be applied to other fields of medical science for comparison of research activity in the Arab world with that in non-Arab countries. Cooperation in urology/nephrology research should be encouraged in the Arab world to bridge the gap with other developed countries.

\section{Abbreviations}

CKD: Chronic kidney disease; SPSS: Statistical package for social sciences; ISI: Institute for Scientific Information; KSA: Kingdom of Saudi Arabia; UAE: United Arab Emirates; SAR: Syrian Arab Republic; USA: United States of America; EU: European Union; JCR: Journal citation report; IRB: Institutional Review Board; SCR: Standard competition ranking; IFs: Impact factors.

\section{Competing interests}

The authors declare that they have no competing interests.

\section{Authors' contributions}

All authors were involved in drafting the article and all authors approved the final version to be submitted for publication. All authors have added an intellectual significant value to the manuscript. WS and SZ were involved in study design and concept. SA and AS were involved in data analysis and manuscript writing. All authors read and approved the final manuscript.

\section{Acknowledgements}

The authors would like to express many thanks and gratitude to An-Najah University for help in conducting this study.

\section{Author details}

${ }^{1}$ Department of Pharmacology and Toxicology, College of Medicine and Health Sciences, An-Najah National University, Nablus, Palestine. ${ }^{2}$ Department of Clinical and Community Pharmacy, College of Medicine and Health

Sciences, An-Najah National University, Nablus, Palestine.

Received: 22 February 2014 Accepted: 11 April 2014

Published: 23 April 2014

\section{References}

1. Wallin JA: Bibliometric methods: pitfalls and possibilities. Basic Clin Pharmacol Toxicol 2005, 97:261-275.

2. De Battisti F, Salini S: Robust analysis of bibliometric data. Stat Methods App/ 2013, 22:269-283.

3. Bramness JG, Henriksen B, Person O, Mann K: A bibliometric analysis of European versus USA research in the field of addiction: research on alcohol, narcotics, prescription drug abuse, tobacco and steroids 2001-2011. Eur Addict Res 2014, 20:16-22.

4. Hofman K, Ryce A, Prudhomme W, Kotzin S: Reporting of non-communicable disease research in low-and middle-income countries: a pilot bibliometric analysis. J Med Libr Assoc 2006, 94:415-420. 
5. Huber JT, Gullion JS: Complementary and alternative medicine as represented in the HIV/AIDS body of knowledge: a bibliometric analysis. Med Ref Serv Q 2003, 22:23-32.

6. Rashidi A, Rahimi B, Delirrad M: Bibliometric analysis of parasitological research in iran and Turkey: a comparative study. Iran J Parasitol 2013, 8:313-322.

7. Zyoud SH, Al-Jabi SW, Sweileh WM, Awang R: Assessing the scientific research productivity of a leading toxicology journal: a case study of human \& experimental toxicology from 2003 to 2012. SAGE Open Med 2014, 2:2050312114523424

8. Zyoud SH, Al-Jabi SW, Sweileh WM: Worldwide research productivity of paracetamol (acetaminophen) poisoning: a bibliometric analysis (2003-2012). Hum Exp Toxicol 2014, Article in press.

9. Al-Khader AA: Enhancing research productivity in the Arab world. Saudi Med J 2004, 25:1323-1327.

10. Benamer HT, Bredan A, Bakoush O: Scientific publication productivity of Libyan medical schools: a bibliometric study of papers listed in PubMed, 1988-2007. Educ Health (Abingdon) 2009, 22:310.

11. Bissar-Tadmouri N, Tadmouri GO: Bibliometric analyses of biomedical research outputs in Lebanon and the United Arab Emirates (1988-2007). Saudi Med J 2009, 30:130-139.

12. Farhat T, Abdul-Sater Z, Obeid M, Arabi M, Diab K, Masri S, Al Haless Z, Nemer G, Bitar F: Research in congenital heart disease: a comparative bibliometric analysis between developing and developed countries. Pediatr Cardiol 2013, 34:375-382.

13. Benamer HT, Bakoush O: Arab nations lagging behind other Middle Eastern countries in biomedical research: a comparative study. BMC Med Res Methodol 2009, 9:26.

14. Zyoud SH, Al-Jabi SW, Sweileh WM, Awang R: A bibliometric analysis of toxicology research productivity in Middle Eastern Arab countries during a 10-year period (2003-2012). Health Res Policy Syst 2014, 12:4.

15. Zer $M$, Lindner $A$, Greenstein A, Leibovici D: Is the rate of medical publication from Israel similar to other countries? A comparative study of three medical specialties. Harefuah 2011, 150:558-562. 619.

16. Abdel-Halim RE: Contributions of Ibn Al-Nafis (1210-1288 AD) to the progress of medicine and urology: a study and translations from his medical works. Saudi Med J 2008, 29:13-22.

17. Gordetsky J, O'Brien J: Urology and the scientific method in ancient Egypt. Urology 2009, 73:476-479.

18. Whiting DR, Guariguata L, Weil C, Shaw J: IDF diabetes atlas: global estimates of the prevalence of diabetes for 2011 and 2030. Diabetes Res Clin Pract 2011, 94:311-321.

19. Afifi A, Karim MA: Renal replacement therapy in Egypt: first annual report of the Egyptian Society of Nephrology, 1996. East Mediterr Health J 1999, 5:1023-1029.

20. Al-Nozha MM, Ali MS, Osman AK: Arterial hypertension in Saudi Arabia. Ann Saudi Med 1997, 17:170-174.

21. Al-Nozha MM, Abdullah M, Arafah MR, Khalil MZ, Khan NB, Al-Mazrou YY, Al-Maatouq MA, Al-Marzouki K, Al-Khadra A, Nouh MS: Hypertension in Saudi Arabia. Saudi Med J 2007, 28:77-84.

22. Farag YM, Kari JA, Singh AK: Chronic kidney disease in the Arab world: a call for action. Nephron Clin Pract 2012, 121:c120-c123.

23. Schena FP, Zoccali C: Bibliometric analysis of the scientific productivity of the Italian Society of Nephrology for a period of five consecutive years (1990-1994). Nephrol Dial Transplant 1996, 11:2359-2360.

24. Einollahi B: Nephrology research output in Iran in a decade. Iran J Kidney Dis 2007, 1:57-62.

25. Zhou X, Xing C, Xin L, Hu H, Li L, Fang J, Liu Z: Scientific publications in urology and nephrology journals from China: a 10-year analysis. Can Urol Assoc J 2012, 6:102-106.

26. Allison MM: Mapping the literature of nephrology nursing. J Med Libr Assoc 2006, 94:E74-E79.

27. Fedder J, Nielsen GL, Petersen LJ, Rasmussen C, Lauszus FF, Frost L, Hornung $N$, Lederballe O, Andersen JP: A substantial number of scientific publications originate from non-university hospitals. Dan Med Bull 2011, 58:A4332.

28. Garg AX, lansavichus AV, Kastner M, Walters LA, Wilczynski N, McKibbon KA Yang RC, Rehman F, Haynes RB: Lost in publication: half of all renal practice evidence is published in non-renal journals. Kidney Int 2006, 70:1995-2005.

29. Hari Kumar KVS, Aravinda K: Publication trends of a biomedical journal from India. Indian J Med Sci 2010, 64:253-258.
30. Thomas GR, Eng L, de Wolff JF, Grover SC: An evaluation of wikipedia as a resource for patient education in nephrology. Semin Dial 2013, 26:159-163.

31. Jabbour S, Giacaman R, Yamout R, Khawaja M, Nuwayhid I: Public health in the Arab World. Cambridge: Cambridge University Press; 2012.

32. Thomson Reuters: Web of Knowledge. In; 2013. [cited 2013 December 11]; Available from: http://wokinfo.com/media/pdf/SSR1103443WoK5-2_web3.pdf.

33. Schreiber M: How relevant is the predictive power of the h-index? A case study of the time-dependent Hirsch index. J Informetrics 2013, 7:325-329.

34. Baldock C, Ma R, Orton CG: The $h$ index is the best measure of a scientist's research productivity. Med Phys 2009, 36:1043.

35. Saied H, Dupré A, Lacki W, Paley D: Pelvic and lower lumber ectopy of kidney in children - with 7 case reports. Ann Urol 1972, 6:227-233.

36. Dunn MD, Portis AJ, Shalhav AL, Elbahnasy AM, Heidorn C, McDougall EM, Clayman RV: Laparoscopic versus open radical nephrectomy: a 9-year experience. J Urol 2000, 164:1153-1159.

37. Siffert W, Forster $\mathrm{P}$, Jockel KH, Mvere DA, Brinkmann B, Naber C, Crookes $R$, Du PHA, Epplen JT, Fridey J, Freedman B, Müller N, Stolke D, Am S, Moutaery K, Grosse-Wilde H, Buerbaum B, Ehrlich T, Hr A, Horsthemke B, Ed Du T, Tiilikainen A, Ge J, Wang Y, Yang D, Hüsing J, Rosskopf D: Worldwide ethnic distribution of the $G$ protein beta3 subunit $825 \mathrm{~T}$ allele and its association with obesity in Caucasian, Chinese, and Black African individuals. J Am Soc Nephrol 1999, 10:1921-1930.

38. Ghoneim MA, el-Mekresh MM, el-Baz MA, el-Attar IA, Ashamallah A: Radical cystectomy for carcinoma of the bladder: critical evaluation of the results in 1,026 cases. J Urol 1997, 158:393-399.

39. Haylen BT, de Ridder D, Freeman RM, Swift SE, Berghmans B, Lee J, Monga A, Petri E, Rizk DE, Sand PK, Schaer GN: An International Urogynecological Association (IUGA)/International Continence Society (ICS) joint report on the terminology for female pelvic floor dysfunction. Int Urogynecol J 2010, 21:5-26.

40. Schwab SJ, Harrington JT, Singh A, Roher R, Shohaib SA, Perrone RD, Meyer K, Beasley D: Vascular access for hemodialysis. Kidney Int 1999, 55:2078-2090.

41. Menon M, Hemal AK, Tewari A, Shrivastava A, Shoma AM, El-Tabey NA, Shaaban A, Abol-Enein H, Ghoneim MA: Nerve-sparing robot-assisted radical cystoprostatectomy and urinary diversion. BJU Int 2003, 92:232-236.

42. Leissner J, Ghoneim MA, Abol-Enein H, Thuroff JW, Franzaring L, Fisch M, Schulze $H$, Managadze G, Allhoff EP, El-Baz MA, Kastendieck H, Buhtz P, Kropf $S$, Hohenfellner R, Wolf HK: Extended radical lymphadenectomy in patients with urothelial bladder cancer: results of a prospective multicenter study. J Urol 2004, 171:139-144.

43. Pedrini LA, Zereik S, Rasmy S: Causes, kinetics and clinical implications of post-hemodialysis urea rebound. Kidney Int 1988, 34:817-824.

44. Eknoyan G, Lameire N, Barsoum R, Eckardt KU, Levin A, Levin N, Locatelli F, MacLeod A, Vanholder R, Walker R, Wang H: The burden of kidney disease: improving global outcomes. Kidney Int 2004, 66:1310-1314.

45. Shalhav AL, Dunn MD, Portis AJ, Elbahnasy AM, McDougall EM, Clayman RV: Laparoscopic nephroureterectomy for upper tract transitional cell cancer: the Washington University experience. J Urol 2000, 163:1100-1104.

46. de Granda-Orive Jl, Alonso-Arroyo A, Roig-Vazquez F: Which data base should we use for our literature analysis? Web of science versus SCOPUS. Arch Bronconeumol 2011, 47:213.

47. Falagas ME, Pitsouni El, Malietzis GA, Pappas G: Comparison of PubMed, Scopus, web of science, and Google scholar: strengths and weaknesses. FASEB J 2008, 22:338-342.

48. Tadmouri GO, Bissar-Tadmouri N: A major pitfall in the search strategy on PubMed. Saudi Med J 2004, 25:7-10.

49. Kulkarni AV, Aziz B, Shams I, Busse JW: Comparisons of citations in Web of Science, Scopus, and Google Scholar for articles published in general medical journals. JAMA 2009, 302:1092-1096.

50. Oelrich $B$, Peters $R$, Jung $K$ : A bibliometric evaluation of publications in urological journals among European Union countries between 2000-2005. Eur Urol 2007, 52:1238-1248.

51. Kou J, Zhang Y, Zhang XG, Liang S, Cai GY, Chen XM: Clinical research promotes development of nephrology in China: an analysis of 20 years of scientific publications. Ren Fail 2012, 34:472-479.

52. Bredan A, Benamer $H$, Bakoush O: Visibility of Arab countries in the world biomedical literature. Libyan J Med 2011, 6:6325.

53. Tadmouri GO, Bissar-Tadmouri N: Biomedical publications in an unstable region: the Arab world, 1988-2002. Lancet 2003, 362:1766.

54. Sweileh WM, Zyoud SH, Sawalha AF, Abu-Taha A, Hussein A, Al-Jabi SW: Medical and biomedical research productivity from Palestine, 2002-2011. BMC Res Notes 2013, 6:41 
55. El-Azami-El-Idrissi M, Lakhdar-Idrissi M, Ouldim K, Bono W, Amarti-Riffi A, Hida M, Nejjari C: Improving medical research in the Arab world. Lancet 2013, 382:2066-2067.

56. Shaban SF, Abu-Zidan FM: A quantitative analysis of medical publications from Arab countries. Saudi Med J 2003, 24:294-296.

57. Al-Khader AA, Al-Jondeby MS, Shaheen FA: Impact of Nephrology publications from Saudi Arabia in the last decade. Saudi Med J 2002, 23:1 177-1180.

58. Lee S, Bozeman B: The impact of research collaboration on scientific productivity. Soc Stud Sci 2005, 35:673-702.

59. Abramo G, D'Angelo CA, Di Costa F: Research collaboration and productivity: is there correlation? High Educ 2009, 57:155-171.

60. Bordons M, Gomez I, Fernandez MT, Zulueta MA, Mendez A: Local, domestic and international scientific collaboration in biomedical research. Scientometrics 1996, 37:279-295.

61. Bozeman B, Corley E: Scientists' collaboration strategies: implications for scientific and technical human capital. Res Policy 2004, 33:599-616.

62. Wagner CS: Six case studies of international collaboration in science. Scientometrics 2005, 62:3-26.

63. He Z-L, Geng X-S, Campbell-Hunt C: Research collaboration and research output: a longitudinal study of 65 biomedical scientists in a New Zealand university. Res Policy 2009, 38:306-317.

64. Basu A, Kumar BSV: International collaboration in Indian scientific papers. Scientometrics 2000, 48:381-402.

65. Nauen CE: Ten years of international scientific cooperation in fisheries, aquaculture and coastal zones: some preliminary lessons. Environ Dev Sustain 2008, 10:605-622.

66. Rahman M, Sakamoto J, Fukui T: Japan's share of research output in urology and nephrology. Int I Urol 2003, 10:353-355.

67. Labanaris AP, Krot D, Schott GE, Helmschrott P, Zugor V: Impact factors and publication time spans in urological journals. Urologe A 2007, 46:297-300. 302

68. Lent $\mathrm{V}$, Langenbach $\mathrm{A}$ : A retrospective quality analysis of 102 randomized trials in four leading urological journals from 1984-1989. Urol Res 1996, 24:119-122.

69. Montorsi F: Current and future trends of publications in urological journals: the increasingly leading role of Europeans. Eur Urol 2007, 52:939-942.

70. Aksnes DW: Characteristics of highly cited papers. Res Eval 2003, 12:159-170.

71. Plomp R: The highly cited papers of professors as an indicator of a research group's scientific performance. Scientometrics 1994, 29:377-393.

72. Aksnes DW, Sivertsen G: The effect of highly cited papers on national citation indicators. Scientometrics 2004, 59:213-224.

73. Aksnes DW: Citation rates and perceptions of scientific contribution J Am Soc Inf Sci Technol 2006, 57:169-185.

74. Fowler JH, Aksnes DW: Does self-citation pay? Scientometrics 2007 , 72:427-437.

75. Vinkler P: Eminence of scientists in the light of the h-index and other scientometric indicators. J Inf Sci 2007, 33:481-491.

76. Zyoud SH, Al-Jabi SW, Sweileh WM: Bibliometric analysis of scientific publications on waterpipe (narghile, shisha, hookah) tobacco smoking during the period 2003-2012. Tob Induc Dis 2014, 12:7.

\section{doi:10.1186/1756-0500-7-258}

Cite this article as: Sweileh et al:: Assessing urology and nephrology research activity in Arab countries using ISI web of science bibliometric database. BMC Research Notes 2014 7:258.

\section{Submit your next manuscript to BioMed Central and take full advantage of:}

- Convenient online submission

- Thorough peer review

- No space constraints or color figure charges

- Immediate publication on acceptance

- Inclusion in PubMed, CAS, Scopus and Google Scholar

- Research which is freely available for redistribution 